\title{
免疫調節薬サリドマイド：薬理学的効果とその適応
}

安井耕三

\section{Thalidomide as immunomodulatory drug : Pharmacological actions and its indications}

\author{
Kozo YASUI \\ Department of Pediatrics, Hiroshima City-Hospital Department of Pediatrics, Okayama University \\ Graduate School of Medicine, Dentistry and Pharmaceutical Sciences
}

(Received July 14, 2010)

summary

Thalidomide was developed in the 1950s as a sedative drug and withdrawn in 1961 because of its teratogenic effects, but has been rediscovered as an immuno-modulatory drug. It has been administered successfully for the treatment of erythema nodosum leprosum, aphthous ulceration and cachexia in HIV disease, inflammatory bowel diseases, and several malignant diseases.

The suppressive effect of thalidomide on the activation of the nuclear transcription factor $\mathrm{NF}-\kappa \mathrm{B}$ may explain these effects of thalidomide. $\mathrm{NF}-\kappa \mathrm{B}$ is retained in the cytoplasm with $\mathrm{I} \kappa \mathrm{B} \alpha$, and is activated by a wide variety of inflammatory stimuli including TNF, IL-1 and endotoxin followed by its translocation to the nucleus. Angiogenesis and organogenesis also require gene transcription and signal translocation. The findings shed new light on the anti-inflammatory properties of thalidomide and suggest pharmaceutical actions of thalidomide via interference of transcription mechanism. I reviewed the effects of thalidomide on auto-inflammatory diseases of childhood.

Key words — thalidomide; Behcet's Disease; Sarcoidosis; $\mathrm{NF}-\kappa \mathrm{B}, \mathrm{TNF}-\alpha$

抄録

サリドマイドは 1950 年代に鎮静催眠薬・不眠薬として開発され，日本を含め多くの国で市販された薬剤であ る。その後 1962 年に催奇形性が明らかとなり，使用が禁止された薬剤であるが，その後 TNF- $\alpha$ 産生抑制作用抢よ び種々の抗腫瘍・免疫調節作用が判明し，多発性骨髄腫やハンセン病（とくに有痛性の結節性紅班），MDS（骨髄 異形成症候群）・AIDS・GVHD（移植片対宿主病）・膿皮症などに使用されその臨床効果が認められている。とく に多剂無効の難治性の炎症性疾患群に対し，薬剤として認可をしなかった唯一の国である米国のFDA が 1998 年 認可し，薬効が確認・再評価されている，本稿ではサリドマイドの免疫系への作用について概説し，筆者らの小児 患者を対象とした臨床研究の成果を紹介した.

\section{はじめに}

サリドマイドは 1950 年代に鎮静催眠薬・不眠薬 として開発され，日本を含め多くの国で市販された 薬剤である。その後 1962 年に催奇形性が明らかと なり，使用が禁止された薬剤であるが，その後 $\mathrm{TNF}-\alpha$ 産生抑制作用および種々の抗腫瘍 ·免疫調 節作用が判明し, 多発性骨髄腫やハンセン病（とく に有痛性の結節性紅班)，MDS（骨髄異形成症候 群) · AIDS - GVHD（移植片対宿主病）・膿皮症な どに使用されその臨床効果が認められている. とく

広島市民病院小児科，岡山大学大学院医歯薬総合研究 科小児医科学
に多剂無効の難治性の炎症性疾患群に対し, 薬剂々 して認可をしなかった唯一の国である米国の FDA が 1998 年認可し, 薬効が確認・再評価されている.

本稿ではサリドマイドの免疫系への作用について 概説し，筆者らの小児患者を対象とした臨床研究の 成果を紹介することにする。

\section{1.サリドマイドによる免疫調節作用効果の発見}

ハンセン病の症状にらい性結節性紅班という皮膚 症状がある. 炎症性の肉芽腫性炎症により末期の強 烈な疼痛を伴った本患者の痛久を軽減させる目的に (鎮痛・睡眠誘導) 使用された本薬剤が，原病の紅 班性肉芽腫病変をも著しく改善させて以来サリドマ 
イドの抗炎症・免疫調節作用が注目されるようにな った。この効果は実に劇的であり，その後本疾患対 象者の実に 99\%の患者において優れた臨床効果が 認められている11.

\section{2. サリドマイドの免疫抑制作用機序}

機序に関しては 1991 年 Kaplan らによってマク ロファージの $\mathrm{TNF}-\alpha$ 産生が抑制されることを報告 している ${ }^{2)}$. TNF- $\alpha$ は免疫反応に不可欠なサイト カインであるが，産生過多は発熱や消耗・体重減少 につながり炎症または肉芽腫形成を引き起こす。工 イズや重症結核・肉芽腫疾患ではこのサイトカイン の過多が消耗性疾患・結節腫形成の原因々考えら れ, サイトカインの産生抢よび機能抑制が病変の改 善をもたらすと考えられている. その後マクロフ アージから産生する $\mathrm{TNF}-\alpha$ の細胞内産生（蛋白造 成）に特異的な細胞内情報伝達分子 $\mathrm{NF} \kappa \mathrm{B}$ の活性 化を刺激因子特異的に抑制することが判明した ${ }^{3)}$.

\section{3. サリドマイドの臨床応用}

\section{1) AIDS}

ヒト免疫不全ウイルスは CD4+ヘルパー $\mathrm{T}$ 細胞 に感染し，免疫調節機構の破綻がもたらされる。そ の後 $\mathrm{TNF}-\alpha$ の過剩産生から悪液質や潰瘍病変が生 じると考えられており，サリドマイドはこうしたエ イズの症状を緩和させることが判明している4,5).

\section{2）ベーチェット病}

ベーチェット病（BD）は, アフタ性口内潰瘍,

外陰部潰瘍, 皮膚症状, 眼症状を, 四主徵とする膠 原病に類似する炎症性疾患である。症状は一般的に 固定することなく，急性増悪と寛解を繰り返しつ つ，徐々に進行する難治性疾患である．小児期での 発症は少ないが，小児例では消化器症状の出現頻度 が高く, 眼症状が少ないこと（不全型が多い）が特 徵である.小児期の BD は全身症状を呈し, 消化器 症状の合併頻度が高い，発熱・疼痛などを繰り返す 症例が多く, 全身病としての加療が必要となる。消 化器病変による症状は腹痛・下血・イレウス症状で あり, 回盲部を中心とする肉芽腫病変のため初発時 虫垂炎という診断をうけることがある。腸管型べー チェット病は極めて難治性の病態であり, 治療はし ばしば高用量ステロイドに依存性となり，患児の QOL は著しく低下する．また病変は穿孔を抢こし やすく，腹膜炎を併発するほか，たびたび再燃を繰 り返す．BDに扔いてはすでに皮膚粘膜所見に対す
るサリドマイド治療の多施設無作為試験により有用 性が比較検討され，その有用性が確認されている6).

高用量 Prednisolone $2 \mathrm{mg} / \mathrm{kg}$ / day の投与やステ ロイドパルス療法は多くの症例において当初有効で あるが，以後減量や中止により容易に症状が再燃し，

Prednisolone 0.5-1.5 mg/kg/day の間で再燃と寛解 を繰り返す。とくに腸管型 BD では, 栄養摂取不良 から, 骨粗鬆症が容易に発症し, 患者の QOL は著 しく低下する。近年注目された薬剂として, 抗 TNF (tumor necrosis factor) $-\alpha$ 抗体 (Infliximab) とサリドマイドが挙げられる.しかし前者は副作用 (播種性結核の発症; TNF- $\alpha$ は結核結節の形成・維 持に必須のサイトカイン, ならびに悪性腫瘍の発 生； 2009 年 FDA から勧告）が懸念される. サリド マイドは投与量も抗炎症効果を狙うには骨髄腫に使 用する量の五分の一程度 (50-100 mg/day) で有効 であり, 副作用も比較的軽微である. また先述した ように特異的な刺激（フリーラジカルやサイトカイ ンなど）による単球の $\mathrm{NF}-\kappa \mathrm{B}$ 転写活性化を抑制す ることが判明している.

\section{3）若年性サルコイドーシス}

サルコイドーシスは, 組織学的に非乾酪性類上皮 細胞肉芽腫からなる病変を認める原因不明の全身性 肉芽腫性炎症性疾患である. 小児のサルコイドーシ スは稀であるが，4歳以下に発症する特異的疾患群 が存在し若年性サルコイドーシス (early onset sarcoidosis；EOS）と呼ばれる. 肺病変は伴わず，皮 虐・関節 - 眼病変を 3 主徵にする疾患群は遺伝性疾 患であり, CARD15/NOD2 遺伝子変異によること が判明している. 自己炎症性疾患に分類されるが, 極めて難治性であり, 多臓器に病変をもたらし, と くに眼病変の予後不良なことが知られている.

岡山大学では, 重篤な症状を呈する男女小児 2 例 を観察している，ステロイドをはじめとした治療に 抵抗性であり, 両者とも CRP $5 \sim 10 \mathrm{mg} / \mathrm{dL},-5 \mathrm{SD}$ 以上の低身長抢よび進行性の網膜疾患を呈してい た. 本疾患の骨・関節所見は破骨細胞の増殖が特徵 的であり, 骨生成阻害が観察される. 皮膚所見も類 上皮細胞の増殖を伴う多核細胞の増殖が観察され る。これらの細胞は骨髄性単球から分化する細胞で あり, 単球マクロファージの異常活性化がその本態 ではないかと疑われる. 実際に患者マクロファージ の分化・増殖能の in vitroでの㠵進を観察した。さ らに患者マクロファージでは恒常的・非特異的に $\mathrm{NF} \kappa \mathrm{B}$ が活性化されており, 破骨細胞やラングハン 


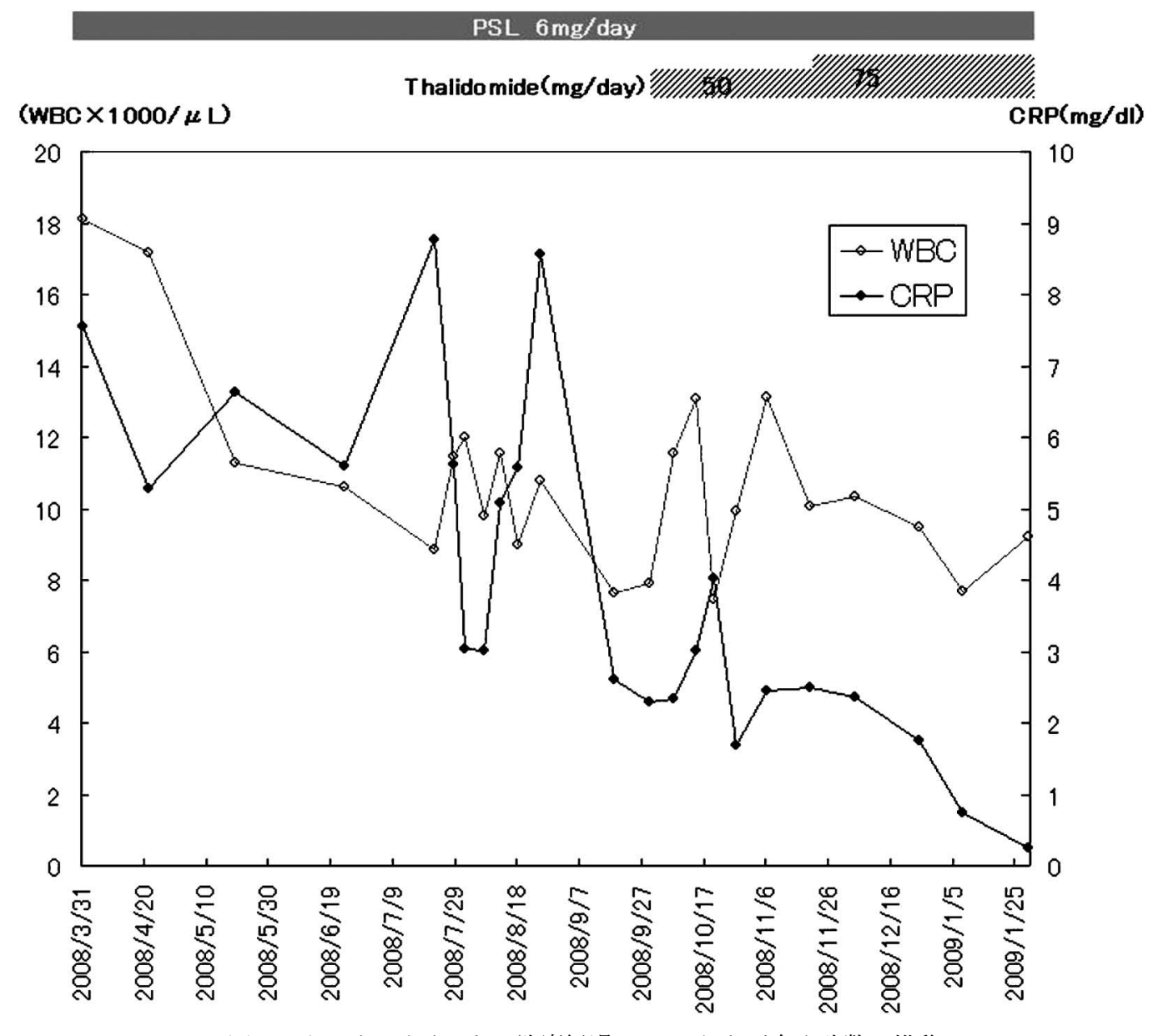

図 1 サリドマイドによる治療経過 CRP および白血球数の推移

(8 y.1mo.)

(8y.10mo.)

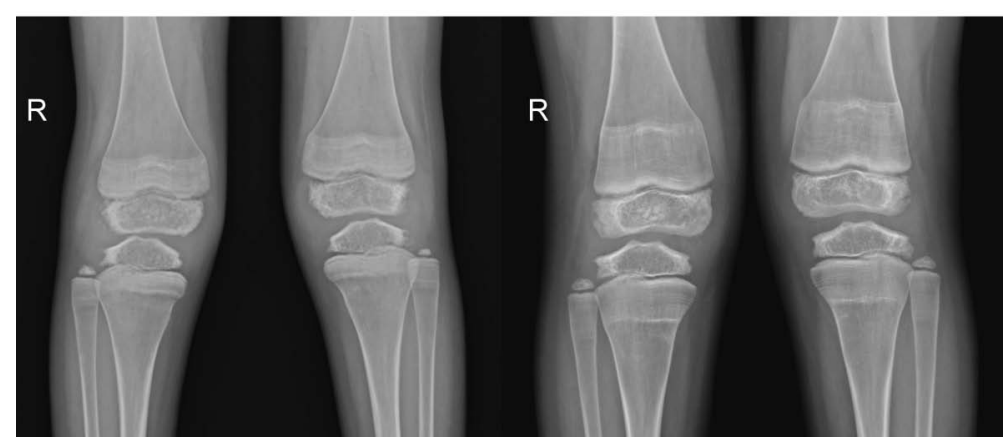

図 2 若年性サルコイドーシスの患者膝関節 治療により 9 カ月で劇的な改善が得られた。

又細胞への分化が $\mathrm{TNF}-\alpha$ 非存在下でも容易に誘導 される、サリドマイドは本病態を画期的に改善させ た7) (図 1,$2 ; \mathrm{X}-\mathrm{P})$. 骨病変とともに網膜病変が改 善し，失明寸前であった視力の回復が得られた。筆 者らはこの作用機序として図 3 に示す病態を考慮し ている。

\section{催奇形の機序と薬理効果の関連性}

サリドマイドの薬害すなわち催奇形性の成因とし て，新生血管の発生抑制が主因と考えられてきた が，この説だけでは四肢に対する特異的な短縮機序 を説明できない.

現在では，四肢発生機序に重要なインテグリンタ 


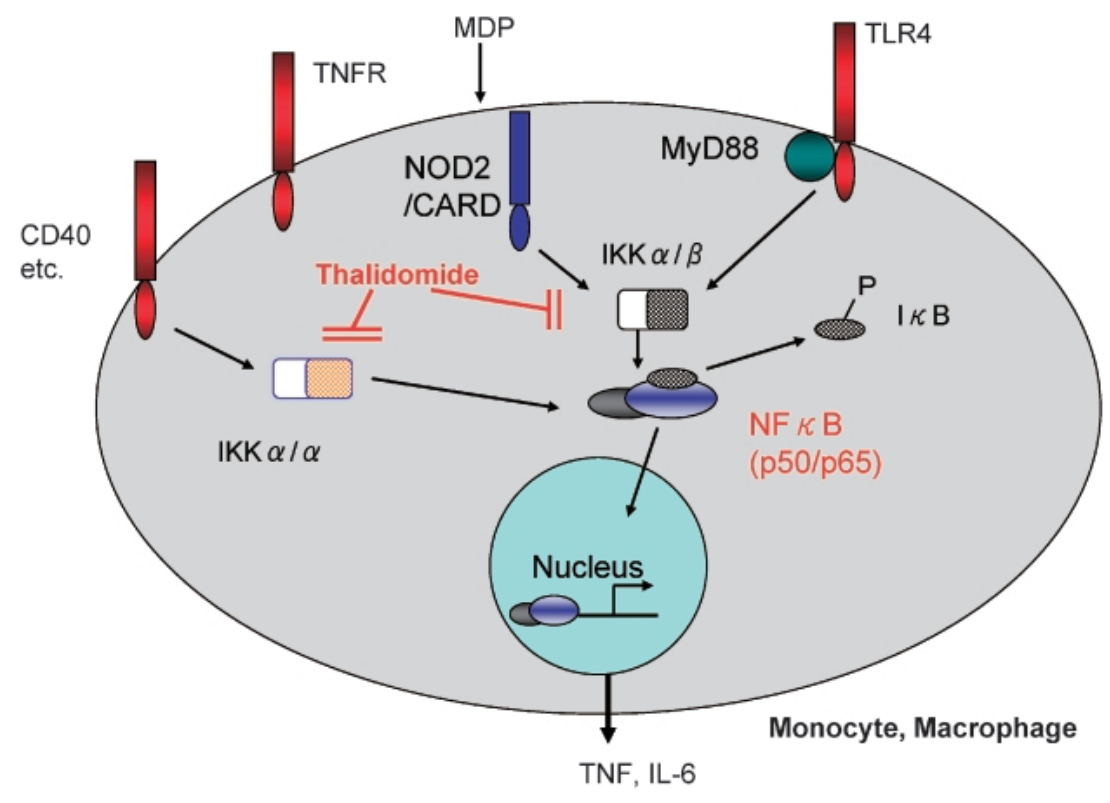

図 3 サリドマイドの作用機序

ンパク遺伝子のプロモーター部分にサリドマイドが インターカレートして遺伝子の転写が損なわれるた め, 新生血管の発生や四肢の分化発生が障害される と考えられている. サリドマイドには炎症性シグナ ルに引き続く転写因子活性のみならず，発生に必要 な遺伝子のタンパク転写抑制機能が引き起こされる ことが，本薬剤の光と影の両面性につながっており サリドマイドが「神と悪魔の薬」8) と称される由縁 となっている。本年（2010年）になってサリドマ イドのターゲットとして cereblon が同定された9).

\section{考案ならびにコメント}

サリドマイドは社会的に多くの問題を持ってきた 薬剤ではあるが，現在使用可能な他の免疫調節薬剤 の全身的副作用と比べると，患者さん自身に与える 影響に限れば決して大きいものではない，胎児に限 って出現する奇形は薬剤管理と患者教育 (STEPS) が徹底されれば，充分克服可能であることは，既に 十年以上本薬剂が認可されている米国の事情を考え れば了解できるであろう。ビリビリといった表現で 訴えられる末梢神経障害には充分な留意が必要であ るが，幸い若年者には出現頻度が低いとされてい る。その臨床的効果は劇的であり，著しく患者の QOL を改善させる，小児患者に限らず，成人患者 さんの将来に亘っても大きな福音となることは疑い ようがない。サリドマイドはわが国でも難治性疾患 に限って抗炎症薬として早期に採用が望まれる薬剤
であると筆者は認識している.

免疫抑制薬として注目される薬剂のなかでも, 生 物学的製剤（抗体治療薬）を除くと期待の持てる新 薬は多くはない. Mycophenolate motefil (MMF) はその中でも有望とされるが，PubMEDの検索で は，抗炎症作用に関するサリドマイドの文献（約 200）が MMF の文献数（約 80）を凌駕している. こうした世界の研究現状は是非認識されなければな らない。

現在のところ日本国内ではサリドマイド治療は治 療施設内での倫理委員会の認可が必要であり, また 薬剂管理の体制が充分に充足していることが求めら れる. また現段階では骨髄腫以外の使用に関しては 輸入薬剂に頼っており, 患者負担が大きいことや保 険外診療である点は今後早急に改善されなければな らないと考えている．また現在国内生産品の薬価が 極めて高額であり, 結果輸入費用と大差ないことも クリアされるべき課題と認識している.

$$
\text { さいごに }
$$

筆者が本薬剂の有効性を初めて知ったのは実は 2002 年冬のあるノンフィクションノベルズ8) との出 会いであった。名著であるので新薬の開発や薬害に 興味のあるドクターには是非一読を勧めるものであ る. 


\section{文献}

1) Sheskin J.: Thalidomide in the treatment of lepra reactions. Clin Pharmacol Ther 6:303306, 1965.

2) Sampaio EP, Sarno EN, Galilly R, et al. : Thalidomide selectively inhibits tumor necrosis factor $\alpha$ production by stimulated human monocytes. J Exp Med 173 : 699-703, 1991

3) Majumdar S, Lamothe B, Aggarwal BB, et al. : Thalidomide suppresses NF-kappa B activation induced by TNF and $\mathrm{H} 2 \mathrm{O} 2$, but not that activated by ceramide, lipopolysaccharides, or phorbol ester. J Immunol 168 : 2644-2651, 2002.

4) Makonkawkeyoon S, Limson-Pobre RN, Moreira AL, et al. : Thalidomide inhibits the replication of human immunodeficiency virus type 1. Proc Natl Acad Sci USA 90 : 5974-5978, 1993.
5) Kaplan G, Thomas S, Fierer DS, et al. : Thalidomide for the treatment of AIDS-associated wasting. AIDS Res Hum Retroviruses 20 : 1345-1355, 2000.

6) Hamuryudan V, Mat $C$, Saip S, et al. : Thalidomide in the treatment of the mucocutaneous lesions of the Behçet syndrome. Ann Intern Med 128 : 443-450, 1998.

7) Yasui $K$, Yashiro $M$, Tsuge $M$, et al. : Thalidomide dramatically improves the symptoms of early-onset sarcoidosis/Blau syndrome: its possible action and mechanism. Arthritis Rheum $62: 250-7,2010$.

8）トレント・ステフェン，ロック・ブリンナー： 神と悪魔の薬サリドマイド。第 1 版, 日経 BP 社, 東京, pp1-318, 2001.

9) Ito $\mathrm{T}$, Ando $\mathrm{H}$, Suzuki $\mathrm{T}$, et al : Identification of a primary target of thalidomide tetragenicity. Science 327 : 1345-1350, 2010. 